JURNAL HUKUM ISLAM

\begin{tabular}{|c|c|c|}
\hline Vol. 4. No. 1 (2021) 42-58 & E-ISSN: : 2723-4681 & P-ISSN: 2722-2764 \\
\hline \multicolumn{3}{|c|}{ Published online on the journal's website: } \\
http://jurnal.iailm.ac.id/index.php/mutawasith
\end{tabular}

\title{
Kedudukan Saksi Non Muslim dalam Perkawinan Menurut Peraturan Perundang-Undangan di Indonesia
}

\author{
Atus Ludin M. \\ Mahasiswa Doktoral Pasca Sarjana UIN Sunan Gunung Djati Bandung \\ Program Studi Hukum Islam \\ aldinmubarok56@gmail.com
}

\begin{tabular}{|c|c|c|}
\hline Received: & Revised: & Published: \\
\hline 30-05-2021 & 07-06-2021 & 05-07-2021 \\
\hline \multicolumn{2}{|c|}{ DOI: https://doi.org/10.47971/mjhi.v4i1.307 } \\
\hline
\end{tabular}

\begin{abstract}
Islam for marriage witnesses is regulated in Indonesian laws and regulations. In the field, it often happens that a Muslim marries a convert to a Muslim woman with a large nonMuslim family status. In marriage, converts submit non-Muslim witnesses. What is the status of their testimony according to the law. The purpose of this study was to determine the position of non-Muslim witnesses to marriage according to the legislation with a qualitative method, a literature study approach. Source of data in the form of legislation related to family law. It is done by deductive-inductive method. From the discussion, it can be concluded that the Indonesian laws and regulations stipulate that marriage witnesses must be Muslim. A non-Muslim is not accepted as a witness to a marriage. In the case of divorce and reconciliation, the witness's special religious requirements are set. There is an opportunity for non-Muslims to be witnesses in ruj'u and divorce cases. Divorce on the grounds of shiqaq must be heard from witnesses who come from the husband and wife's family. That is, Article 76 of Law no. 7/1989 paragraph (1) still applies to family and close people of husband and wife who are non-Muslims and must provide testimony as witnesses. Keywords: non-Muslim, marriage, witness, law
\end{abstract}

\section{Abstrak}

Beragama Islam bagi saksi nikah diatur dalam peraturan perundang-undangan di Indonesia. Di lapangan sering terjadi seorang muslim menikahi perempuan mu'alaf dengan status keluarga besar non muslim. Dalam pernikahan muallaf mengajukan saksi non muslim. Bagaimana status kesaksian mereka menurut perundang-undangan. Tujuan penelitian ini untuk mengetahui kedudukan saksi non muslim perkawinan menurut perundang-undangan dengan metode kualitatif, pendekatan studi kepustakaan. Sumber Data berupa peraturan perundang-undangan terkait hukum keluarga. Dilakukan dengan metode deduktif-induktif. Dari pembahasan disimpulkan, peraturan perundang-undangan Indonesia menetapkan, saksi nikah harus beragama Islam. Seorang non muslim tidak 
diterima menjadi saksi nikah. Pada masalah perceraian dan rujuk menetapkan syarat khusus keagamaan saksi. Ada peluang non muslim menjadi saksi pada perkara ruj'u dan perceraian. Perceraian dengan alasan syiqaq harus didengar keterangan saksi-saksi yang berasal dari keluarga suami istri. Artinya, Pasal 76 UU No. 7/1989 ayat (1) tetap berlaku bagi keluarga dan orang-orang dekat suami-isteri yang non muslim dan harus memberikan keterangan sebagai saksi.

Kata Kunci: non muslim, perkawinan, saksi, undang-undang

\section{A. PENDAHULUAN}

Perkawinan adalah ikatan yang sangat kuat (mitsaqan ghalizan) dan secara esensial memiliki dimensi horizontal dan vertikal (transcendental) (UU No. 1 Tahun 1974 Pasal 1) untuk membangun keluarga bahagia, harmonis, sejahtera, unggul, dan berkualitas yang turut berkontribusi dalam mewujudkan program pembangunan keluarga seutuhnya. ${ }^{1}$ (Muhamad Dani Somantri, Dahwadin, dan Faisal, 2018). Perkawinan dipandang sebagai sakralitas amal atas wujud ketundukan seorang hamba kepada Allah SWT (ibadah) untuk kemudian mampu melanjutkan legalisasi estapet keberlangsungan hidup manusia yang secara fitrah senantiasa mengalami pertumbuhan fisik dan perkembangan psikis. Ketika akad telah diucapkan oleh seorang calon suami, maka disitu terdapat hak dan kewajiban masing-masing mempelai akan berlangsungnya perkawinan setelah akad diucapkan oleh seorang laki-laki²

Dalam dimensi horizontal, ikatan perkawinan sarat dengan hak dan kewajiban timbal balik antara suami isteri, menimbulkan hubungan keperdataan terhadap anak-anak, serta dalam makna yang lebih luas mengandung tanggung jawab terhadap keluarga dan masyarakat. Sedang dalam dimensi vertikal, ikatan perkawinan merupakan realisasi ibadah (penghambaan diri) kepada Allah Swt dalam rangka mengikuti sunnah Rasulullah SAW serta amanah yang harus dipertanggung jawabkan, baik di dunia maupun di akhirat (Atus Ludin Mubarok dan Muhamad Dani Somantri, 2019). Kekuatan ikatan perkawinan juga dapat dilacak dari tujuannya dimana secara jelas Kompilasi Hukum Islam (KHI) pasal 3 menyebutkan bahwa "Perkawinan bertujuan untuk mewujudkan kehidupan rumah tangga yang sakînah, mawaddah, dan rahmah"3

Pernikahan adalah peristiwa sakral. Mengingat pentingnya acara tersebut, ada persyaratan dalam upacara pernikahan. Salah satu syarat wajib dalam sebuah pernikahan adalah kehadiran seorang saksi. Mayoritas ulama fiqh sepakat bahwa pernikahan tidak sah jika tidak ada saksi (Dahwadin, dkk, 2019, h. 66). Dalam berbagai tahapan akad nikah, saksi setidaknya menjalankan dua peran penting.

\footnotetext{
${ }^{1}$ Muhamad Dani Somantri, Dahwadin, and Faisal, "Analisa Hukum Menunda Kehamilan Perkawinan Usia Dini Perspektif Istihsan Sebuah Upaya Membangun Keluarga Berkualitas," Jurnal Mahkamah : Jurnal Kajian Hukum Islam Vol. 3 No. 2. Desember. (2018).

2 Somantri, Dahwadin, and Faisal.

3 “Kompilasi Hukum Islam," n.d.
} 
Pertama, sebagai "perantara" yang akan akan menginformasikan (i'lân) kepada orang banyak. Sebab, Nabi Saw menyuruh memberitahukan adanya pernikahan, diantaranya, dengan mengadakan bunyi-bunyian. Kedua, sebagai jaminan penerimaan (al-qabûl) orang banyak bahwa pernikahan itu telah berlangsung secara sah dan benar. Dalam pelaksanaan akad nikah, mayoritas ulama menyebut bahwa saksi menjadi salah satu rukunnya, disamping empat rukun lain yaitu shîghä̈, calon suami, calon istri, dan wali ${ }^{4}$.

Lima rukun dalam pernikahan dinyatakan berlaku secara positif bagi umat Islam Indonesia. Hal itu dinyatakan dalam Pasal $14 \mathrm{KHI}$ yang secara tegas menyebutnya sebagai rukun: "Untuk melaksanakan perkawinan harus ada: a. calon suami; b. calon isteri; c. wali nikah; d. dua orang saksi dan; e. ijab dan kabul. Keberadaan saksi sebagai rukun nikah ini dipertegas oleh Pasal 24 ayat (1), bahwa "Saksi dalam perkawinan merupakan rukun pelaksanaan akad nikah". Sementara jumlah saksi yang harus ada dalam akad nikah disebutkan dalam ayat (2), bahwa Setiap perkawinan harus disaksikan oleh dua orang saksi (UU No. 1 Tahun 1974 Pasal 26). Peraturan perundang-undangan Indonesia justru menetapkan bahwa dalam dua tahapan tersebut tetap harus ada saksinya. UU No. 7 tahun 1989 tentang Peradilan Agama dalam pasal 70 ayat (2) menjelaskan: Setelah penetapan tersebut memperoleh kekuatan hukum tetap, Pengadilan menentukan hari sidang penyaksian ikrar talak, dengan memanggil suami dan isteri atau wakilnya untuk menghadiri sidang tersebut (UU No. 7 Tahun 1989 Pasal 70 ayat (2)).

Sementara pengukuhan saksi dalam rujuk disebutkan dalam Kompilasi Hukum Islam pasal 167 dijelaskan tentang tata cara rujuk oleh suami, datang bersama isterinya ke Pegawai Pencatat Nikah atau Pembantu Pegawai Pencatat Nikah yang mewilayahi tempat tinggal suami isteri dengan membawa penetapan tentang terjadinya talak dan surat keterangan lain yang diperlukan (ayat [1]). Pada ayat (4) disebutkan "Setelah itu suami mengucapkan rujuknya dan masing-masing yang bersangkutan besrta saksi-saksi menandatangani Buku Pendaftaran Rujuk". Walau KHI tidak menggunakan istilah rukun rujuk, tapi aturan pada ayat (4) ini sangat jelas menempatkan peran saksi sebagai penentu dalam penyelesaian sebuah perkara, kesaksian berperan sangat penting. Sebuah kesaksian berlaku mengikat, karena Syâri' menjadikannya sebagai ḥujjä̆ dalam proses hukum, meski dalam kesaksian itu tetap terdapat kemungkinan adanya kebohongan.

Disamping itu, semua pihak membutuhkannya dalam tiap perkara dan sengketa. Kalau kesaksian tidak diterima, akan sangat sulit untuk mendatangkan alat bukti yang meyakinkan, karena banyaknya sengketa dalam masyarakat. Karena itu, kebenaran sebuah kesaksian sangat ditentukan oleh kualitas dan kapasitas

${ }^{4}$ Aḥmad bin Ghânim al-Mâlikî, Al-Fawâkih al-Dîwânî 'Alâ Risâlăh Ibn Abî Zayd al-Qayrawânî (Beirut: Dar al-Fikr, 1995), 405. 
orang yang menjadi saksi. Untuk memberikan jaminan kebenaran informasi yang disampaikannya itulah kemudian para ulama menetapkan berbagai syarat yang harus dipenuhi seorang saksi. Demikian pentingnya peran kesaksian, seperti dinyatakan al-Sarakhsî, Rasulullah Saw pernah menegaskan "muliakanlah para saksi, karena Allah Swt menghidupkan yang hak melalui mereka ${ }^{5}$. Allah Swt sendiri menyatakan kemulian umat Muhammad karena posisi mereka sebagai saksi terhadap seluruh manusia. Salah satu syarat terpenting saksi adalah sebagai muslim atau beragama Islam ${ }^{6}$.

Syarat beragama Islam bagi saksi tersebut, khususnya untuk akad nikah, juga diadopsi sepenuhnya oleh peraturan perundangan Indonesia. Dalam KHIPasal 25 hal itu secara tegas dapat ditemukan. Di mana Pasal itu menyebutkan: "Yang dapat ditunjuk menjadi saksi dalam akad nikah ialah seorang laki-laki muslim, adil, aqil baligh, tidak terganggu ingatan dan tidak tuna rungu atau tuli". Sementara Pasal 26 menegaskan keharusan saksi untuk hadir dan menandatangani Akta Nikah dalam pelaksanaan akad nikah. Konsekwensi dari adanya syarat keislaman tersebut, menafikan kesaksian yang diberikan oleh orang-orang yang tidak beragama Islam (non muslim atau kafir). Hal itu disebabkan karena seorang non muslim tidak bisa disebut adil (yang dituntut surat al-Thalâq [65] ayat 2) dan tidak termasuk bagian dari "kita" (yang dituntut surat al-Baqarä̈ [2] ayat 282).

Dalam perkawinanpun banyak terjadi seorang lelaki muslim menikahi perempuan mu'alaf dengan status keluarga besarnya tetap non muslim. Malah tidak jarang ada orang-orang yang beragama Islam menikah dengan perempuan non muslim. Sementara dalam proses pernikahan mereka yang muallaf atau non muslim mengajukan saksi yang non muslim. Dengan ini, permasalahan yang muncul adalah bagaimana status kedudukan mereka sebagai saksi dan kesaksian mereka. Fenomena tersebut menjadi dasar yang cukup jelas untuk menganalisa lebih jauh dan lebih dalam terhadap masalah kedudukan saksi non muslim dalam perkawinan perundang-undangan Indonesia.

\section{B. METODOLOGI}

Dalam paradigma ilmu sosial, penelitian seperti ini termasuk jenis penelitian kualitatif (naturalistic paradigm) 7. 8; 9 . Untuk memperoleh informasi yang berkaitan dengan persoalan penelitian digunakan pendekatan kepustakaan (library research), yaitu dengan menggali literatur-literatur yang membahas tentang

\footnotetext{
${ }^{5}$ Zakariyâ, Fath Al-Wahhâb Bi Syarh Manhaj al-Thullâb (Beirut: Dâr al-Ma'rifah̆, 1993), 112.

${ }^{6}$ Abdul Aziz Dahlan, Ensiklopedi Hukum Islam (Jakarta: PT. Ichtiar Van Hoeve, 1997), 1335.

${ }^{7}$ Lexy J. Moleong, Metodologi Penelitian Kualitatif (Bandung: Remaja Rosda Karya, 1998), 3.

${ }^{8}$ Suharsimi Arikunto, Prosedur Penelitian; Suatu Pendekatan Praktek (Jakarta: Rineka Cipta, 2002), 13

${ }^{9}$ Moh Nazir, Metode Penelitian (Jakarta: Ghalia Indonesia, 1988), 32-34.
} 
konsep saksi dalam sistem peraturan hukum di Indonesia, khususnya saksi non muslim. Peter Mahmud Marzuki menuliskan ${ }^{10}$, hakikat dari pendekatan ini adalah untuk menemukan kebenaran objek hukum.

\section{HASIL PENELITIAN DAN PEMBAHASAN}

\section{Konsep Non Muslim dalam Paradigma Perundang-Undangan}

Untuk memahami makna kata non muslim, mau tak mau, harus ditelusuri dari kata muslim itu sendiri. Sebab, kata "non" merupakan morfem terikat yang ditambahkan di awal kata yang mengandung makna 'tidak' atau 'bukan' (Tim Penyusun Kamus Bahasa Indonesia, 2008:1006). Sebagai sebuah morfem, ia merupakan satuan bentuk bahasa terkecil yang mempunyai makna; bentuk kata, seperti me-, di- dan sebagainya ${ }^{11}$. Ia disebut terikat karena ia tak dapat berdiri sendiri; selalu terikat pada kata lain untuk mombentuk ujaran yang berupa kalimat 12 .

Kata muslim merupakan nominal yang berarti orang yang memeluk agama Islam atau penganut agama Islam. Lazimnya kata ini mengacu pada lelaki yang beragama Islam, karena perempuan penganut agama Islam disebut muslimat. Sementara kata yang digunakan untuk menggambarkan bentuk jamaknya adalah muslimin, para penganut agama Islam atau orang-orang muslim ${ }^{13}$. Dengan demikian, kata non muslim berarti orang yang 'tidak' memeluk agama Islam atau 'bukan' penganut agama Islam.

Di dunia, diperkiraan ada sekitar 4.200 agama, yang diklasifikasikan jadi dua: Pertama, agama universal yang mencari penerimaan di seluruh dunia dan secara aktif mencari anggota baru. Kedua, agama etnis yang diidentifikasi dengan kelompok etnis tertentu dan tidak mencari orang baru untuk bertobat pada agamanya. Pada abad ke-19 dan ke-20, praktek akademik perbandingan agama membagi keyakinan agama ke dalam tiga kategori, yaitu: Pertama, agama-agama dunia atau agama internasional. Kedua, agama pribumi, yang mengacu pada yang lebih kecil, budaya-tertentu atau kelompok agama-negara tertentu. Ketiga, gerakan-gerakan keagamaan baru ${ }^{14}$.

Di Indonesia sendiri, berdasar Penjelasan Pasal 1 Undang-undang Nomor 1/PNPS/1965 tentang Pencegahan Penyalahgunaan dan/atau Penodaan Agama, Lembaran Negara Republik Indonesia Tahun 1965 Nomor 3, disebutkan bahwa: "Agama-agama yang dipeluk oleh penduduk di Indonesia ialah Islam, Kristen, 2008), 95.

${ }^{10}$ Peter Mahmud Marzuki, Penelitian Hukum (Jakarta: Kencana Prenada Media Group,

${ }^{11}$ Tim Penyusun Kamus, Kamus Bahasa Indonesia (Jakarta: Departemen Pendidikan Nasional, 2008), 971.

12972 .

13988.

${ }^{14}$ Graham Harvey, Indigenous Religions: A Companion (New York: Cassell, 2000), 6. 
Katolik, Hindu, Budha dan khonghuCu (Confusius). Hal ini dapat dibuktikan dalam sejarah perkembangan agama-agama di Indonesia"(UU No. 3 Tahun 1965 Tentang Penodaan Agama).

Ini tidak berarti bahwa agama-agama lain, misalnya: Yahudi, Zarasustrian, Shinto, Taoism dilarang di Indonesia. Mereka mendapat jaminan penuh seperti yang diberikan oleh pasal 29 ayat 2 dan mereka dibiarkan adanya, asal tidak melanggar ketentuan-ketentuan yang terdapat dalam peraturan ini atau peraturan perundangan lain. Hanya saja 6 macam agama yang disebutkan adalah agama yang dipeluk mayoritas penduduk Indonesia. Karena itu mereka mendapat jaminan seperti yang diberikan oleh pasal 29 ayat 2 Undang-Undang Dasar dan mendapat bantuan-bantuan dan perlindungan dari penyalahgunaan dan/atau penodaan agama.

Mengikuti bahasa yang digunakan UU No. 1/PNPS/1965, maka yang dimaksud dengan non muslim di Indonesia adalah orang yang tidak memeluk agama Islam, yaitu mereka yang memeluk agama Kristen, Katolik, Hindu, Budha dan Khonghucu (Confusius). Termasuk juga dalam kategori non muslim adalah mereka yang meyakini agama Yahudi, Zarasustrian, Shinto, Taoism, dan agama lokal atau yang sering disebut agama keyakinan atau aliran kepercayaan.

Sikap negara terhadap perbedaan agama warga negara Indonesia. Dalam penjelasan umum UU No. 12 tahun 2006 tentang Kewarganegaraan Republik Indonesia disebutkan asas-asas yang dianut dalam undang-undang ini, sebagai berikut (UU No. 12 Tahun 2006 tentang Kewarganegaraan Republik Indonesia):

Asas ius sanguinis (law of the blood) adalah asas yang menentukan kewarganegaraan seseorang berdasarkan keturunan, bukan berdasarkan negara tempat kelahiran.

a) Asas ius soli (law of the soil) secara terbatas adalah asas yang menentukan kewarganegaraan seseorang berdasarkan negara tempat kelahiran, yang diberlakukan terbatas bagi anak-anak sesuai dengan ketentuan yang diatur dalam undang-undang ini.

b) Asas kewarganegaraan tunggal adalah asas yang menentukan satu kewarganegaraan bagi setiap orang.

c) Asas kewarganegaraan ganda terbatas adalah asas yang menentukan kewarganegaraan ganda bagi anak-anak sesuai dengan ketentuan yang diatur dalam undang-undang ini.

Selain asas itu, beberapa asas khusus juga menjadi dasar penyusunan Undang-Undang tentang Kewarganegaraan Republik Indonesia ini, yaitu:

a) Asas kepentingan nasional adalah asas yang menentukan bahwa peraturan kewarganegaraan mengutamakan kepentingan nasional Indonesia, yang bertekad mempertahankan kedaulatannya sebagai negara kesatuan yang memiliki cita-cita dan tujuannya sendiri. 
b) Asas perlindungan maksimum adalah asas yang menentukan bahwa pemerintah wajib memberikan perlindungan penuh kepada setiap Warga Negara Indonesia dalam keadaan apapun baik di dalam maupun di luar negeri.

c) Asas persamaan di dalam hukum dan pemerintahan adalah asas yang menentukan bahwa setiap Warga Negara Indonesia mendapatkan perlakuan yang sama di dalam hukum dan pemerintahan.

d) Asas kebenaran substantif adalah prosedur pewarganegaraan seseorang tidak hanya bersifat administratif, tetapi juga disertai substansi dan syaratsyarat permohonan yang dapat dipertanggungjawabkan kebenarannya.

e) Asas nondiskriminatif adalah asas yang tidak membedakan perlakuan dalam segala hal ikhwal yang berhubungan dengan warga negara atas dasar suku, ras, agama, golongan, jenis kelamin dan gender.

f) Asas pengakuan dan penghormatan terhadap hak asasi manusia adalah asas yang dalam segala hal ikhwal yang berhubungan dengan warga negara harus menjamin, melindungi, dan memuliakan hak asasi manusia pada umumnya dan hak warga negara pada khususnya.

g) Asas keterbukaan adalah asas yang menentukan bahwa dalam segala hal ihwal yang berhubungan dengan warga negara harus dilakukan secara terbuka.

h) Asas publisitas adalah asas yang menentukan bahwa seseorang yang memperoleh atau kehilangan Kewarganegaraan Republik Indonesia diumumkan dalam Berita Negara Republik Indonesia agar masyarakat mengetahuinya.

Beberapa asas tersebut, khususnya asas non diskriminatif, menegaskan bahwa tidak ada perbedaan perlakuan dalam segala hal, dalam konteks ini yang berhubungan dengan agama yang dianut warga negara. Hal itu secara jelas disebutkan dalam Pasal 27 UUD 1945 ayat 1, bahwa "Segala warga negara bersamaan kedudukannya di dalam hukum dan pemerintahan serta wajib menjunjung hukum dan pemerintah dengan tidak terkecuali". Hal senada juga dimuat dalam Pasal 3 ayat (2) UU No. 39 tahun 1999 tentang Hak Asasi Manusia, bahwa "Setiap orang berhak atas pegakuan, jaminan, perlindungan dan perlakuan hukum yang adil serta mendapat kepastian hukum dan perlakuan yang sama di depan hukum".

Berkaiatan dengan kehidupan beragama, Negara juga memberikan jaminan penuh dalam memeluk dan beribadah menurut agamanya. Hal itu dimuat dalam Pasal 28 E ayat (1) UUD 1945, bahwa "Setiap orang bebas memeluk agama dan beribadat menurut agamanya, memilih pendidikan dan pengajaran, memilih pekerjaan, memilih kewarganegaraan, memilih tempat tinggal di wilayah negara dan meninggalkannya, serta berhak kembali." 
Pasal 28 E ayat (2) UUD 1945 juga menyatakan bahwa setiap orang berhak atas kebebasan meyakini kepercayaan. Selain itu dalam Pasal 28I ayat (1) UUD 1945 juga diakui bahwa hak untuk beragama merupakan hak asasi manusia. Selanjutnya Pasal 29 ayat (2) UUD 1945 juga menyatakan bahwa Negara menjamin kemerdekaan tiap-tiap penduduknya untuk memeluk agama.

Akan tetapi, hak asasi tersebut bukannya tanpa pembatasan. Dalam Pasal 28J ayat (1) UUD 1945 diatur bahwa setiap orang wajib menghormati hak asasi orang lain. Pasal 28J ayat (2) UUD 1945 selanjutnya mengatur bahwa pelaksanaan hak tersebut wajib tunduk pada pembatasan-pembatasan dalam undang-undang. Jadi, hak asasi manusia tersebut dalam pelaksanaannya tetap patuh pada pembatasanpembatasan yang diatur dalam undang-undang.

Oleh karena itu, selama tidak ada aturan khusus, pada dasarnya tidak ada pembatasan boleh atau tidaknya seseorang menjadi saksi di pengadilan berdasar agama yang ia anut. Dengan kata lain, hanya hukumlah yang jadi dasar untuk menetapkan dilarang atau tidaknya seseorang untuk memberikan kesaksian.

\section{Saksi Non Muslim pada Perkawinan dalam Timbangan Perundang-Undangan}

Secara khusus, di Indonesia terdapat hukum positif yang mengatur tentang perkawinan, yaitu UU No. 1 tahun 1974. UU ini merupakan norma hukum yang berlaku mengikat untuk semua Warga Negara Indonesia dimana pun berada. Walau tidak mengatur secara rinci, dalam UU ini juga disinggung masalah saksi dalam perkawinan. Pengaturan lebih teknis tentang saksi tersebut dapat ditermui dalam berbagai peraturan turunan UU ini. Dengan demikian, UU ini dan produk turunannya menjadi batasan untuk boleh atau tidaknya seseorang menjadi saksi dalam perkawinan.

a. Kesaksian non muslim dalam akad nikah

Arti penting saksi ini dalam UU No 1/1974 tentang perkawinan dapat ditemukan dalam Pasal 26 ayat (1) yang menyebutkan bahwa:

Perkawinan yang dilangsungkan dimuka pegawai pencatat perkawinan yang tidak berwenang, wali-nikah yang tidak sah atau yang dilangsungkan tanpa dihadiri oleh 2 (dua) orang saksi dapat dimintakan pembatalannya oleh para keluarga dalam garis keturunan lurus keatas dari suami atau isteri, jaksa dan suami atau isteri.

Penggunaan kata "dapat" dalam ayat ini sesungguhnya tidak menempatkan peran saksi dalam makna paling strategis. Sebab, konsekwensi dari penggunaan kata itu adalah ketika tidak ada keluarga atau pihak lain yang mengajukan pembatalan perkawinan, maka perkawinan itu dipandang sah secara hukum. Peran strategis saksi ini baru kelihatan dalam Kompilasi Hukum Islam (KHI), yang bermula dari Pasal 1 huruf c, bahwa "Akad nikah ialah rangkaian ijab yang diucapkan oleh wali dan kabul yang diucapkan oleh mempelai pria atau wakilnya disaksikan oleh dua orang saksi". 
Bunyi aturan dalam pasal tersebut secara jelas memperlihatkan bahwa sebuah transaksi baru disebut akad nikah, atau sebuah akad nikah baru disebut sah, kalau di dalamnya terdapat tiga unsur penting, yaitu: ijab oleh wali atau wakilnya, kabul oleh mempelai pria atau wakilnya, dan dua orang saksi. Artinya, kalau salah satu unsurnya tidak ada, maka ia bukan akad nikah atau akad nikahnya tidak sah. $\mathrm{Hal}$ inilah yang kemudian disebut dengan rukun dan dirinci dalam Pasal $14 \mathrm{KHI}$, bahwa "Untuk melaksanakan perkawinan harus ada:

1) Calon Suami;

2) Calon Isteri;

3) Wali nikah;

4) Dua orang saksi dan;

5) ljab dan Kabul.

Sabagai salah satu rukun dari akad nikah, maka ketiadaan saksi akan membuat akad nikah atau perkawinan itu batal demi hukum. Sebab, dalam posisinya sebagai rukun, dua orang saksi tersebut setara dengan calon suami, calon isteri atau rukun lainnya. Hal itu secara nyata juga ditegaskan dalam Pasal 24 ayat (1) KHI, bahwa "Saksi dalam perkawinan merupakan rukun pelaksanaan akad nikah". Sedang pada ayat (2) Pasal 24 juga ditegaskan peran saksi tersebut dalam akad nikah, "Setiap perkawinan harus disaksikan oleh dua orang saksi".

Hal senada juga dimuat dalam Peraturan Pemerintah (PP) Nomor 09 tahun 1975 tentang Pelaksanaan UU No. 1 tahun 1974, Pasal 10 ayat (3), bahwa "Dengan mengindahkan tatacara perkawinan menurut masing-masing hukum agamanya dan kepercayaannya itu, perkawinan dilaksanakan dihadapan Pegawai Pencatat dan dihadiri oleh dua orang saksi".

Aturan tersebut juga sekaligus memberikan panduan bahwa keberadaan saksi bukan hanya sekedar "membubuhkan" tanda tangan pada akta nikah; mereka harus hadir pada saat akad nikah dilaksanakan. Hal itu secara tegas juga dinyatakan dalam Pasal 26 KHI, bahwa "Saksi harus hadir dan menyaksikan secara langsung akdan nikah serta menandatangani Akta Nikah pada waktu dan ditempat akad nikah dilangsungkan".

Bukan hanya itu, KHI justru memberikan peran saksi sebelum akad nikah dilangsungkan; mereka juga menyaksikan apakah perkawinan itu dilakukan secara sukarela. Hal itu terbaca dari Pasal 17 ayat (1) KHI yang menyebutkan "Sebelum berlangsungnya perkawinan Pegawai Pencatat Nikah menanyakan lebih dahulu persetujuan calon mempelai dihadapan dua saksi nikah".

Untuk peran strategsi seperti itulah KHI menetapkan syarat khusus saksi dalam akad nikah ini, yang disebut dengan Saksi Nikah. Hal itu disebutkan dalam Pasal 25, bahwa "Yang dapat ditunjuk menjadi saksi dalam akad nikah ialah seorang laki-laki muslim, adil, aqil baligh, tidak terganggu ingatan dan tidak tuna rungu atau 
tuli". Persyratan ini ditegaskan dan dirinci dalam Pasal 19 Peraturan Menteri Agama (PMA) No. 11/2007, tentang Pencatatan Nikah, sebagai berikut:

1) Akad nikah harus dihadiri sekurang-kurangnya dua orang saksi.

2) Saksi sebagaimana dimaksud pada ayat (1) harus memenuhi syaratsyarat:
a) Laki-laki;
b) Beragama Islam;
c) Baligh, berumur sekurang-kurangnya 19 tahun;
d) Berakal;
e) Merdeka; dan
f) Dapat berlaku adil.

3) PPN, Penghulu, dan/atau Pembantu PPN dapat diterima sebagai saksi.

Di sini jelas sekali bahwa KHI dan PMA No. 11/2007 menggunakan kriteria saksi yang dikemukakan oleh ulama fikih. Dimana orang yang diterima sebagai saksi dalam akad nikah tersebut adalah seorang muslim, disamping syarat lain. Hal ini tentu saja berlaku untuk pernikahan antara sesama muslim. Sebab, Pasal $40 \mathrm{KHI}$ melarang perkawinan antara seorang lelaki muslim dengan perempuan yang tidak beragama Islam.

Sebagai produk turunan dari UU No. 1 tahun 1974, KHI hanya berlaku untuk sebagian warga negara yang beragama Islam. Hal itu jugalah yang jadi salah satu dasar penggunaan inpres sebagai instrument pengundangannya. Sebab, apabila dijadikan undang-undang, maka $\mathrm{KHI}$ harus berlaku bagi seluruh warga negara. Sedangkan masyarakat selain Islam tidak akan menerimanya, karena KHI merupakan produk Islam, tanpa melibatkan agama lain.

Sementara aturan tentang saksi dalam pernikahan sesama non muslim, mengikuti aturan yang terdapat dalam peraturan perundangan lazimnya, seperti yang telah dijelaskan pada bab III. Di mana tidak ada syarat harus menganut agama tertentu. Dalam hal ini juga termasuk perkawinan antara muslim dan non muslim, yang diselenggarakan dan dicatat di Catatan Sipil.

Peran penting saksi ini, setelah akad nikah dilangsungkan, disebutkan dalam Pasal 11 PP No. 9 tahun 1975, berikut:

a. Sesaat sesudah dilangsungkannya perkawinan sesuai dengan ketentuan-ketentuan Pasal 10 Peraturan Pemerintah ini, kedua mempelai menandatangani akta perkawinan yang telah disiapkan oleh Pegawai Pencatat berdasarkan ketentuan yang berlaku.

b. Akta perkawinan yang telah ditandatangani oleh mempelai itu, selanjutnya ditandatangani pula oleh kedua saksi dan Pegawai Pencatat yang menghadiri perkawinan dan bagi yang melangsungkan perkawinan menurut agama Islam, ditandatangani pula oleh wali nikah atau yang mewakilinya. 
c. Dengan penandatanganan akta perkawinan, maka perkawinan telah tercatat secara resmi.

Aturan tersebut menempatkan saksi, melalui tanda tangannya, menjadi pihak yang tercantum dan menjadi bukti bahwa perkawinan itu sah. Sebab, secara hukum, sebuah perkawinan yang sah hanya dapat dibuktikan dengan akta nikah. Secara tegas hal ini dimuat dalam Pasal 7 ayat (1) KHI, yaitu: "Perkawinan hanya dapat dibuktikan dengan Akta Nikah yang dibuat oleh Pegawai Pencatat Nikah".

Panduan tegas yang dapat dilihat dari semua aturan tersebut, bahwa saksi dalam akad nikah antara sesama muslim haruslah seorang muslim. Dalam hal ini, berbagai aturan yang ada tidak memberikan alternative sama sekali untuk saksi ini. Artinya, agar perkawinan antara seorang muslim dengan muslim lainnya dipandang sah secara hukum, maka saksi yang dihadirkan dalam akad nikah itu haruslah seorang muslim.

b. Kesaksian non muslim dalam talak

Talak merupakan salah satu penyebab putusnya perkawinan, disamping beberapa penyebab yang disebutkan dalam Pasal $113 \mathrm{KHI}$. Lebih khusus lagi, talak adalah bagian dari penyebab kedua yang disebutkan pasal tersebut, karena perceraian. Sebab perceraian dapat terjadi karena dua cara, seperti disebutkan pasal Pasal 114, yaitu karena talak dan gugatan perceraian. Secara teknis, sebab perceraian yang pertama disebut Cerai Talak (CT) dan sebab yang kedua disebut Cerai Gugat (CG).

Perbedaan penting antara dua penyebab perceraian tersebut terletak pada pihak yang melakukan inisiatif dalam mengajukan gugatan perceraian. Inisiatif pengajuan gugatan pada Cerai Talak adalah suami, yang dalam wacana fikih lazim disebut talak saja. Sementara pada Cerai Gugat, inisiatif pengajuan gugatan dilakukan oleh pihak isteri, yang lebih kurang sepadan dengan khulu' dalam wacana fikih.

Secara hukum, putusnya perkawinan hanya dapat dibuktikan dengan akta perceraian yang dikeluarkan Pengadilan Agama. Hal itu menunjukkan secara tegas bahwa Pengadilan Agama memegang peran menentukan dalam proses perceraian. Pada Pasal 65 UU No. 7/1989 hal itu disebutkan secara jelas, bahwa "Perceraian hanya dapat dilakukan di depan sidang Pengadilan setelah Pengadilan yang bersangkutan berusaha dan tidak berhasil mendamaikan kedua belah pihak".

Aturan dalam Pasal 65 UU No. 7/1989 itu memberikan gambaran bahwa sebelum perceraian atau talak terjadi, para pihak yang ingin bercerai terlebih dahulu harus melalui proses perkara di pengadilan. Proses perkara itu sendiri merupakan upaya guna menyaksikan ikrar talak. Pada dasarnya proses beracara Cerai Talak dan Cerai Gugat di Pengadilan Agama, selain pihak yang mengajukan gugata, adalah sama. Hal itu pada dasarnya mengikuti aturan dalam Pasal 66 UU No. 7/1989, berikut: 
1) Seorang suami yang beragama Islam yang akan menceraikan istrinya mengajukan permohonan kepada Pengadilan untuk mengadakan sidang guna menyaksikan ikrar talak.

2) Permohonan sebagaimana yang dimaksud dalam ayat (1) diajukan kepada Pengadilan yang daerah hukumnya meliputi tempat kediaman termohon, kecuali apabila termohon dengan sengaja meninggalkan tempat kediaman yang ditentukan bersama tanpa izin pemohon.

3) Dalam hal termohon bertempat kediaman di luar negeri, permohonan diajukan kepada Pengadilan yang daerah hukumnya meliputi tempat kediaman pemohon.

4) Dalam hal pemohon dan termohon bertempat kediaman di luar negeri, maka permohonan diajukan kepada Pengadilan yang daerah hukumnya meliputi tempat perkawinan mereka dilangsungkan atau kepada Pengadilan Agama Jakarta Pusat.

5) Permohonan soal penguasaan anak, nafkah anak, nafkah istri, dan harta bersama suami istri dapat diajukan bersama-sama dengan permohonan cerai talak ataupun sesudah ikrar talak diucapkan.

Salah satu peran penting saksi dalam proses perceraian ini adalah dalam proses berperkara di sidang pengadilan ini. Diantaranya disebutkan dalam Pasal 76 UU No. 7/1989, berikut:

1) Apabila gugatan perceraian didasarkan atas alasan syiqaq, maka untuk mendapatkan putusan perceraian harus didengar keterangan saksisaksi yang berasal dari keluarga atau orang-orang yang dekat dengan suami istri.

2) Pengadilan setelah mendengar keterangan saksi tentang sifat persengketaan antara suami istri dapat mengangkat seorang atau lebih dari keluarga masing-masing pihak ataupun orang lain untuk menjadi hakam.

Dalam hal itu, fungsi saksi adalah guna membuktikan kebenaran dalil gugatan atau sanggahan para pihak yang berperkara. Setelah melakukan pemeriksaan, dan dalam setiap prosesnya selalu diupayakan perdamaian antara para pihak, baru hakim mengambil kesimpulan untuk mengabulkan atau tidak gugatan yang diajukan. Kalau gugatan tersebut dikabulkan, maka Pasal 70 ayat (3) UU No. 7/1989 menyebutkan: "Setelah penetapan tersebut memperoleh kekuatan hukum tetap, Pengadilan menentukan hari sidang penyaksian ikrar talak, dengan memanggil suami dan istri atau wakilnya untuk menghadiri sidang tersebut".

Untuk melakukan ikrar talak itu sendiri si suami hanya diberi tenggang waktu selama enam bulan sejak hari yang ditentukan mejalis hakim. Kalau dalam masa itu si suami atau wakilnya tidak melakukan ikrar talak di pengadilan, maka putusan itu jadi gugur, perceraian tidak terjadi dan tidak dapat mengajukan perkara yang sama 
dengan alasan yang sama. Hal itu diatur dalam Pasal 70 ayat (6) UU No. 7/1989, bahwa:

Jika suami dalam tenggang waktu 6 (enam) bulan sejak ditetapkan hari sidang penyaksian ikrar talak, tidak datang menghadap sendiri atau tidak mengirim wakilnya meskipun telah mendapat panggilan secara sah atau patut maka gugurlah kekuatan penetapan tersebut, dan perceraian tidak dapat diajukan lagi berdasarkan alasan yang sama.

Kalimat "penyaksian ikrar talak" dalam pasal 70 ayat (3) dan ayat (6) sekaligus memberikan penekanan bahwa: Pertama, UU No. 7/1989 menganut prinsip bahwa talak harus "disaksikan" di hadapan sidang Pengadilan Agama. Kedua, Majelis hakim dan Panitera yang hadir dalam sidang ikrar talak adalah orang-orang yang bertindak sebagai saksi talak yang dilakukan.

Lebih lanjut, PP No. 09/1975 Pasal 17 memberikan arahan bahwa perceraian itu "dikukuhkan" dengan surat keterangan tentang terjadinya perceraian. Pasal ini menegaskan "Sesaat setelah dilakukan sidang pengadilan untuk menyaksikan perceraian yang dimaksud dalam Pasal 16, Ketua Pengadilan membuat surat keterangan tentang terjadinya perceraian tersebut. Surat keterangan itu dikirimkan kepada Pegawai Pencatat di tempat perceraian itu terjadi untuk diadakan pencatatan perceraian".

Berkaitan dengan saksi pada perceraian ini, terlihat ada dua "kategori" saksi: Pertama, saksi yang berfungsi sebagai alat bukti. Kedua saksi peristiwa ikrar talak. Saksi kategori kedua ini dapat diyakini bahwa mereka adalah orang-orang yang beragama Islam. Sebab, syarat personalitas hakim peradilan agama meliputi pengetahuan hukum Islam dan keterampilan menerapkan hukum dengan integritas pribadinya (Arifin 1996:86). Di samping itu, salah satu syarat untuk menjadi Hakim pada Pengadilan Agama yang ditetapkan Pasal 13 UU No. 071989 adalah beragama Islam. Artinya, para hakim dan pegawai PA adalah orang-orang yang memenuhi syarat sebagai saksi.

Sementara saksi yang sangat berpeluang untuk berbeda agama dengan para pihak yang berperkara di Pengadilan Agama adalah saksi kategori pertama. Sebab dalam beberapa kasus para pihak yang berperkara merasa lebih dekat dan lebih percaya kepada orang-orang tersebut untuk memberikan keterangan tentang perkara yang mereka hadapi. Di samping itu, memang tidak selalu persoalan yang dihadapi seorang muslim terjadi dan disaksikan oleh saudaranya sesama muslim.

Berbeda dengan saksi pada akad nikah, yang secara tegas disebut sebagai rukun dan ditetapkan syaratnya oleh KHI, dalam UU No. 1/1974, UU yang terkait dan beberapa peraturan turunannya tidak ditemukan penegasan spesifik tantang syarat saksi pada perkara perceraian ini. Kalau mengikuti "kehendak" persyaratan saksi pada Saksi Nikah, maka saksi pada perkara perceraian ini tentu juga "laki-laki 
muslim, adil, aqil baligh, tidak terganggu ingatan dan tidak tuna rungu atau tuli", dan itulah saksi terbaik dalam kasus ini.

Hal itu diperkuat oleh salah satu asas utama yang melekat pada undangundang peradilan agama, yaitu asas keislaman. Asas ini bermakna bahwa pihak yang tunduk dan dapat ditundukkan kepada kekuasaan di lingkungan peradilan agama hanya warga nergara yang beragama Islam. Dengan kata lain, keislaman seseoranglah yang menjadi dasar kewenangan pengadilan agama di lingkungan peradilan agama. Karena itu, penganut agama non Islam tidak tunduk dan tidak dapat dipaksakan tunduk kepada kekuasaan peradilan agama (Undang-Undang Nomor 3 Tahun 2006).

Akan tetapi, selain kepercayaan kepada non muslim dan ketiadaan muslim saat peristiwa, peraturan perundangan sendiri juga membuka peluang itu terjadi. Salah satunya "keterangan saksi-saksi yang berasal dari keluarga atau orang-orang yang dekat dengan suami istri." terdapat pada Pasal 76 UU No. 7/1989 yang juga senada dengan muatan Pasal 22 PP No. 9/1975. Hal ini sangat mungkin terjadi pada pernikahan yang salah satunya masih muallaf, dan keluarganya yang lain masih non muslim.

Penyebab lain, karena ketiadaan penegasan spesifik syarat saksi pada perceraian, para hakim "terkondisikan" untuk mengikuti aturan yang terdapat dalam Pasal 54 UU No. 7/1989, bahwa "Hukum acara yang berlaku pada Pengadilan dalam lingkungan Peradilan Agama adalah hukum acara Perdata yang berlaku pada Pengadilan dalam lingkungan Peradilan Umum, kecuali yang telah diatur secara khusus dalam Undang-Undang ini".

\section{c. Kesaksian non muslim dalam rujuk}

Pada dasarnya rujuk adalah mengembalikan perempuan yang ditalak, selain talak bâ'in, pada perkawinan selama perempuan itu masih dalam masa idah tanpa akad nikah baru. Secara normative, hal ini diatur dalam Pasal $163 \mathrm{KHI}$, berikut:

1) Seorang suami dapat merujuk isterunya yang dalam masaiddah.

2) Rujuk dapat dilakukan dalam hal-hal :

a) putusnya perkawinan karena talak, kecuali talak yang telah jatuh tiga kali talak yang dijatuhkan qobla al dukhul;

b) putusnya perkawinan berdasarkan putusan pengadilan dengan alasan atau alasan-alasan selain zina dan khuluk.

Kalau ada dan sahnya sebuah perkawinan secara hukum harus dibuktikan dengan akta nikah, maka ada dan sahnya rujuk dibuktikan dengan kutipan Buku Pendaftaran Rujuk yang dikeluarkan oleh Pegawai Pencatat Nikah, sebagaimana diatur dalam Pasal $10 \mathrm{KHI}$. Secara formal, keberadaan saksi terlihat pada saat pengurusan akta ini. 
Arti penting saksi itu dimulai dari penyaksian kesediaan si isteri untuk dirujuk suaminya, sebagaimana dimuat dalam Pasal 164 KHI. Sementara proses rujuk itu sendiri diatur dalam Pasal $167 \mathrm{KHI}$, sebagai berikut:

1) Suami yang hendak merujuk isterinya datang bersama-sama isterinya ke Pegawai Pencatat Nikah atau Pembantu Pegawai Pencatat Nikah yang mewilayahi tempat tinggal suami isteri dengan membawa penetapan tentang terjadinya talak dan surat keterangan lain yang diperlukan

2) Rujuk dilakukan dengan persetujuan isteri dihadapan Pegawaii Pencatat Nikah atau Pembantu Pegawai Pencatat Nikah.

3) Pegawai Pencatat Nikah atau Pembantu Pegawai Pencatat Nikah memeriksa dan meyelidiki apakah suami yang akan merujuk itu memenuhi syarat-syarat merujuk menurut hukum munakahat, apakah rujuk yang akan dilakukan masih dalam iddah talak raj'i, apakah perempuan yang akan dirujuk itu adalah isterinya.

4) Setelah itu suami mengucapkan rujuknya dan masing-masing yang bersangkutan besrta saksi-saksi menandatangani Buku Pendaftaran Rujuk.

5) Setelah rujuk itu dilaksanakan, Pegawai Pencatat Nikah atau Pembantu Pegawai Pencatat Nikah menasehati suami isteri tentang hukum-hukum dan kewajiban mereka yang berhubungan dengan rujuk.

Muatan hukum yang terdapat dalam Pasal $167 \mathrm{KHI}$ memberikan penegasan jelas terhadap beberapa hal: Pertama, rujuk hanya dapat dilakukan kalau si isteri bersedia untuk dirujuk suaminya. Kedua, suami isteri yang akan rujuk harus memenuhi syarat, seperti si isteri masih berada dalam masa 'idah talak raj'î, tentu saja, si suami tidak memiliki isteri lebih dari tiga (empat dengan yang akan dirujuk), dan lain-lain. Ketiga, rujuk harus dilakukan secara lisan, tidak bisa dengan perbuatan saja. Keempat, rujuk harus di hadapan saksi. Kelima, peristiwa rujuk harus dicatat yang dalam keadaan tertentu dapat dijadikan sebagai alat bukti. Sebab akta rujuk adalah akta autentik tentang pencatatan peristiwa rujuk.

Dalam banyak hal, saksi pada masalah rujuk ini tidak diatur selengkap saksi pada akad nikah dan perceraian. Walau ada kesan kemiripan rujuk dengan akad nikah, menyatukan (kembali) suami isteri, tetapi saksi tidak dinyatakan secara tegas sebagai rukun rujuk dan tidak diatur secara spesifik persyaratannya. Tetapi, saksi pada rujuk berperan hampir sama dengan saksi pada akad nikah, yaitu "mempersaksikan" terjadinya peristiwa hukum penyatuan (kembali) suami isteri; pengucapan ikrar rujuk oleh suami. Di sinilah perbedaannya dengan saksi pada perkara perceraian, yang hanya memberikan keterangan keabsahan dalil gugatan dan sangkalan para pihak.

Walau berbeda dalam fungsi, akan tetapi ketidak jelasan syarat saksi pada rujuk sama dengan perkara perceraian. Karena itu, kalau memperhatikan 
"semangat" yang diemban beberapa peraturan yang terkait dengan perkawinan dan terutama sekali $\mathrm{KHI}$, maka mestinya syarat saksi pada rujuk ini juga sama dengan syarat saksi pada akad nikah, yaitu "laki-laki muslim, adil, aqil baligh, tidak terganggu ingatan dan tidak tuna rungu atau tuli". Sama seperti pada perkara perceraian, saksi terbaik dalam rujuk ini adalah yang memenuhi persyaratan tersebut.

Dalam hal ini, penulis kira sangat tepat kalau Pegawai Pencatat Nikah (PPN) dan/atau Penghulu menetapkan dan menegaskan keharusan mendatangkan saksi yang memenuhi persyaratan tersebut. Sebab, seperti disebut dalam Penjelasan Pasal 1 UU No, 22/1946, tentang Pencatatan Nikah, Nikah, Talak Dan Rujuk, dalam tugas dan wewenang pengawasan nikah/rujuk yang diembankan kepadanya, selain bermakna hadir pada akad nikah dan rujuk, juga terkandung makna memeriksa ada tidaknya rintangan dan apakah syarat-syarat yang ditentukan oleh Hukum Agama Islam tidak dilanggar.

Akan tetapi, dari pedoman yang terdapat dalam berbagai peraturan perundangan lebih mengarahkan pada pemenuhan syarat formal yang ditetapkan dalam hukum acara perdata. Sebagai contoh, dalam Pasal 45 ayat (1) PMA No. 3/1975, tentang Kewajiban Pegawai Pencatat Nikah dan Tata Kerja Pengadilan Agama dalam Melaksanakan Peraturan Perundang-undangan Perkawinan Bagi yang Beragama Islam, disebutkan: "Saksi-saksi yang hadi pada waktu pencatatan nikah, talak, cerai dan rujuk, dipilih oleh mereka yang berkepentingan sendiri, saksisaksi itu harus warga negara Indonesia dan harus sudah mencapai umur 19 tahun dan memenuhi syarat-syarat menurut hukum".

Di sini jelas sekali bahwa unsur nasionalisme dan kecakapan rasional lebih diprioritaskan sebagai syarat saksi pada "Perkawinan Bagi yang Beragama Islam". Ditambah dengan berbagai argument pada syarat saksi perkara perceraian sebelumnya, maka dapat disimpulkan bahwa secara hukum tidak ada halangan seorang yang non muslim menjadi saksi pada rujuk yang dilakukan oleh pasangan muslim.

\section{KESIMPULAN}

Dengan merujuk pada keterangan di atas, maka peraturan perundangundangan Indonesia, khususnya Pasal 25 KHI, menetapkan bahwa saksi dalam akad nikah atau perkawinan haruslah seorang yang beragama Islam. Karena itu, seorang yang non muslim juga tidak diterima untuk menjadi saksi akad nikah tersebut. Sementara pada masalah perceraian dan rujuk, peraturan perundangan tidak menetapkan syarat khusus keagamaan saksinya. Karena itu, ada peluang orang non muslim untuk menjadi saksi dalam dua peristiwa hokum ini, terutama sekali pada perkara perceraian. Di mana Pasal 76 UU No. 7/1989 ayat (1) menyebut bahwa perceraian dengan alasan syiqaq, maka harus didengar keterangan saksi-saksi yang 
berasal dari keluarga atau orang-orang yang dekat dengan suami istri. Artinya, Pasal 76 UU No. 7/1989 ayat (1) tersebut tetap berlaku bagi keluarga dan orangorang dekat suami-isteri yang non muslim, dan harus memberikan keterangan sebagai saksi.

\section{REFERENSI}

Arifin, Bustanul. Pelembagaan Hukum Islam Di Indonesia; Akar Sejarahh Dan Prospeknya. Jakarta: Gema Insani Press, 1996.

Arikunto, Suharsimi. Prosedur Penelitian; Suatu Pendekatan Praktek. Jakarta: Rineka Cipta, 2002.

Aziz Dahlan, Abdul. Ensiklopedi Hukum Islam. Jakarta: PT. Ichtiar Van Hoeve, 1997. Harvey, Graham. Indigenous Religions: A Companion. New York: Cassell, 2000.

J. Moleong, Lexy. Metodologi Penelitian Kualitatif. Bandung: Remaja Rosda Karya, 1998.

"Kompilasi Hukum Islam,"

Mahmud Marzuki, Peter. Penelitian Hukum. Jakarta: Kencana Prenada Media Group, 2008.

Mâlikî, Aḥmad bin Ghânim al-. Al-Fawâkih al-Dîwânî 'Alâ Risâlä̆ Ibn Abî Zayd alQayrawânî. Beirut: Dar al-Fikr, 1995.

Nazir, Moh. Metode Penelitian. Jakarta: Ghalia Indonesia, 1988.

Somantri, Muhamad Dani, Dahwadin, and Faisal. "Analisa Hukum Menunda Kehamilan Perkawinan Usia Dini Perspektif Istihsan Sebuah Upaya Membangun Keluarga Berkualitas." Jurnal Mahkamah : Jurnal Kajian Hukum Islam Vol. 3 No. 2. Desember. (2018).

Tim Penyusun Kamus. Kamus Bahasa Indonesia. Jakarta: Departemen Pendidikan Nasional, 2008.

"Undang-Undang Perkawinan No. 1 Tahun 1974.

Zakariyâ. Fath Al-Wahhâb Bi Syarh Manhaj al-Thullâb. Beirut: Dâr al-Ma'rifäh, 1993. 